\title{
The effect of hempseed expellers on selected quality indicators of broiler chicken's meat
}

\author{
Ondřej Št’astník ${ }^{1^{*}}$, Miroslav Jůzl ${ }^{2}$, Filip Karásek ${ }^{1}$, Dominika Fernandová ${ }^{1}$ \\ Eva Mrkvicová ${ }^{1}$, Leoš Pavlata ${ }^{1}$, Śárka Nedomová $^{2}$, Tomáš Vyhnánek ${ }^{3}$, Václav Trojan ${ }^{3}$, \\ Petr Doležal ${ }^{1}$
}

Mendel University in Brno, ${ }^{1}$ Department of Animal Nutrition and Forage Production, ${ }^{2}$ Department of Food Technology, ${ }^{3}$ Department of Plant Biology, Brno, Czech Republic

Received September 26, 2018

Accepted February 12, 2019

\begin{abstract}
The aim of the study was to evaluate the effect of feeding hempseed expellers in a feed mixture on the quality indicators of broiler chicken's meat. One hundred and fifty Ross 308 hybrid cockerels were used in the present study. The control group (HS0) was fed without hempseed expellers; the other two groups received diets containing $50 \mathrm{~g} \cdot \mathrm{kg}^{-1}$ and $150 \mathrm{~g} \cdot \mathrm{kg}^{-1}$ of hempseed expellers (HS5 and HS15, respectively). The birds were slaughtered at the age of 37 days, and samples of breast and thigh muscles were collected for determination of proximate chemical composition and technological properties, and sensory analyses. Feeding with hempseed expellers influenced the colour of meat with a significant difference observed for $a^{*}$ (redness) and $b^{*}$ (yellowness) values in the HS15 group. The colour of breast meat in HS15 group is more intense compared to HS5 and HS0 groups. Breast meat was evaluated as the best in terms of odour for HS15 group compared to HS0. The colour of thigh meat was better rated in the HSE supplemented groups compared to the controls. In conclusion, dietary supplementation with hempseed expellers appears to affect the colour and odour of broiler chicken's meat which is positive for the consumers. Including hempseed cakes can be recommended as a component of broiler chicken's feed.
\end{abstract}

Cannabis sativa L., poultry nutrition, meat quality

After extracting oil from hempseeds (Cannabis sativa L.), the remaining hempseed expellers may be used as an alternative non-conventional animal feed, since they contain a high amount of proteins and active substances. Although hempseed expellers seem to be a promising alternative protein feed for animals, only few studies exist describing the effects of incorporating hempseed expellers in animal diets (Karlsson et al. 2010). Whole hempseed contains approximately $35.5 \%$ oil, $24.8 \%$ crude protein and $22 \mathrm{MJ} \cdot \mathrm{kg}^{-1}$ metabolisable energy. The fibre content in whole hempseed and seed meal is $27.6 \%$ and $42.6 \%$, respectively. The two main proteins in hempseed are edestin (also known as edistin) and albumin which are of high-quality and easily digestible (Callaway 2004). Hempseed protein is free of trypsin inhibitors and oligosaccharides found in soybeans that often cause upset stomach and gas. Hemp has therefore been used in traditional medicine for the flatulence therapy (Erikss on and Wall 2012). Another advantage of hempseed is the presence of the nonpsychotic cannabinoid cannabidiol (CBD) which is a metabolite of tetrahydrocannabinol (THC). Cannabidiol has been shown to have antioxidant, antibacterial, anti-inflammatory and immune stimulating effects (Hampson et al. 1998; Straus 2001). Tetrahydrocannabinol is a potent lipophilic antioxidant with appetitestimulating properties (Hampson et al. 2000; Koch 2001).

The quality of meat is determined by many factors that can be evaluated and measured by laboratory techniques. The consumers' opinion regarding the sensory characteristics of meat plays an important role as well. The diets used in poultry determine the basic indicators of the production, nutritive value, and partially taste and odour of meat. Poultry

Address for correspondence:

Ondřej Št'astník

Department of Animal Nutrition and Forage Production

Mendel University in Brno

Zemědělská 1, 61300 Brno, Czech Republic 
meat, especially breast meat, is characterized by a high nutritive value. Consumers desire meat with adequate flavour, high nutritive value, low fat content and high concentrations of vitamins and minerals (Grabowski 2014). Dietary supplementation with hempseed expellers could be positively evaluated by the consumers, provided it does not affect the quality or price of meat. The natural colour of food is due to carotenoids, anthocyanins, and chlorophyll (Rodriguez-Amaya 2016). These substances are commonly found in animal feed of vegetable origin and could also be detected in the final products (meat, eggs etc.). These natural pigments also have a health promoting potential (Rodriguez-Amaya 2016). There has been an increased demand in foods that are not only safe, but also induce health benefits so new functional foods have been examined all over the world (Obradovic et al. 2014). Meat quality can be determined by $\mathrm{pH}$ and sensory evaluation. Many authors agree that the $\mathrm{pH}$ value 15 to $30 \mathrm{~min}$ after slaughter can be a reliable indicator of broiler meat quality (Glamoclija et al. 2015).

The objective of this study was to evaluate the effect of adding hempseed expellers (Cannabis sativa L.) in a typical feed mixture for broiler chickens on the meat characteristics. The sensory characteristics and quality indicators of the chicken meat were then assessed to determine if the addition of hempseed expellers to the diet improved meat quality and affected the overall consumer preference.

\section{Materials and Methods}

Animals and diets

The hempseed expellers used in the study were a by-product of hempseeds of the Carmagnola variety that were pressed to produce oil. The commercial product of hempseed expellers was purchased from Hempoint, s.r.o. (Jihlava, Czech Republic). In general, hempseed expellers on dry matter basis contain $298.04 \mathrm{~g} \cdot \mathrm{kg}^{-1} \mathrm{crude}$ protein, $96.94 \mathrm{~g} \cdot \mathrm{kg}^{-1}$ crude fat, $325.53 \mathrm{~g} \cdot \mathrm{kg}^{-1}$ crude fibre, $72.46 \mathrm{~g} \cdot \mathrm{kg}^{-1}$ ash, $18.72 \mathrm{mg} \cdot \mathrm{kg}^{-1} \beta$-carotene and $46.62 \mathrm{mg} \cdot \mathrm{kg}^{-1}$ cyanidine-3-glucoside and $170 \mathrm{mg} \cdot \mathrm{kg}^{-1}$ of CBD. The content of tetrahydrocannabinol and cannabinol (CBN) were non-detectable in the feed. The contents of $\beta$-carotene and cyanidine-3-glucoside were measured by previously published methods (Bulda et al. 2008; Varga et al. 2013) and the cannabinoid content was measured by the gas-chromatography method (Lalge et al. 2016).

The experiment was performed with 150 cockerels of the Ross 308 hybrid. A conventional deep litter system was used with wood shavings as the bedding material. The study started when the chicks were at the age of 12 days and lasted for 25 days (till the $37^{\text {th }}$ day of age). Room temperature and humidity were controlled according to the requirements for the production of Ross 308 chickens (Technological procedure for Broiler Ross 2014). The lighting system was maintained at a 16-h light and 8-h dark light cycle. Cockerels were divided into three equal groups. The control group (HS0; $n=50$ ) was fed diets without the addition of hempseed expellers, while the two experimental groups were fed diets containing $50 \mathrm{~g} \cdot \mathrm{kg}^{-1}(\mathrm{HS} 5 ; \mathrm{n}=50)$ and $150 \mathrm{~g} \cdot \mathrm{kg}^{-1}(\mathrm{HS} 15 ; \mathrm{n}=50)$ of hempseed expellers. The three isocaloric and isonitrogenous diets were formulated according to the recommended nutrient content for poultry (Zelenka et al. 2007). The animal procedures were reviewed and approved by the Animal Care Committee of Ministry of Education Youth and Sports Czech Republic (MSMT - 4180/2016-7).

The chemical compositions of hempseed expellers and diets were determined for dry matter, crude protein, crude fat, crude fibre, and ash according to the EC Commission Regulation (Commission Regulation 152/2009). The composition and nutrient contents of diets are shown in Tables 1 and 2.

The health status of animals was evaluated daily and live weight was measured every week during the trial. The chickens were fed ad libitum. At the end of the experiment ( $37^{\text {th }}$ day of age), 15 birds were randomly selected from each group, weighed and slaughtered by decapitation. The feathers were removed, the chickens were eviscerated, and the carcass yield was calculated. The breast and thigh muscles without skin were separated from the carcasses after cooling. All visible external fat was removed from the sample muscles. The breast and thigh meat was weighed and their percentages of live body weight were calculated.

Meat $\mathrm{pH}$

The $\mathrm{pH}$ of the 6 samples per group was measured using a $\mathrm{pH}$ meter (Portavo 907, Knick Elektronische Messgeräte $\mathrm{GmbH} \& \mathrm{Co}$. KG, Berlin, Germany) with a needle-type electrode (SE104N; Knick Elektronische Messgeräte $\mathrm{GmbH} \& \mathrm{Co}$. KG, Berlin, Germany) 15 min after slaughter $\left(\mathrm{pH}_{1}\right)$ and $6 \mathrm{~h}$ post mortem $\left(\mathrm{pH}_{\mathrm{ult}}\right)$ in $\mathrm{m}$. pectoralis major. Each measurement was performed twice, and the mean was calculated.

Meat analysis

Meat samples from the left part of the breast and the left thigh were wrapped in aluminium foil, marked and stored at $-20{ }^{\circ} \mathrm{C}$ until sensory analysis (6 samples per group). Meat from the right half of the breast and 
Table 1. Composition of the experimental diets $\left(\mathrm{g} \cdot \mathrm{kg}^{-1}\right)$.

\begin{tabular}{lccc}
\hline Components & HS0 & HS5 & HS15 \\
\hline Wheat & 378.2 & 271.9 & 279 \\
Maize & 247 & 287.5 & 283 \\
Hempseed expellers & 0 & 50 & 150 \\
Soybean meal & 105 & 120 & 100 \\
Soybean extruded & 190 & 190 & 78 \\
Rapeseed oil & 20 & 30 & 40 \\
Wheat gluten & 18.8 & 10.1 & 30 \\
Premix* & 30 & 30 & 30 \\
Monocalcium phosphate & 7 & 6.5 & 5 \\
CaCO & 4 & 4 & 5 \\
\hline
\end{tabular}

Diet HS0 was the control, whereas HS5 and HS15 diets contained $50 \mathrm{~g} \cdot \mathrm{kg}^{-1}$ and $150 \mathrm{~g} \cdot \mathrm{kg}^{-1}$ of hempseed expellers, respectively.

* Premix contains (per kg): lysine $60 \mathrm{~g}$; methionine $75 \mathrm{~g}$; threonine $34 \mathrm{~g}$; calcium $200 \mathrm{~g}$; phosphorus $65 \mathrm{~g}$; sodium $42 \mathrm{~g}$; copper 500 $\mathrm{mg}$; iron 2,500 mg; zinc 3,400 mg; manganese 4,000 mg; cobalt $7 \mathrm{mg}$; iodine $30 \mathrm{mg}$; selenium $6 \mathrm{mg}$; tocopherol $450,000 \mathrm{mg}$; calciferol 166,700 IU (international units); phylloquinone $50 \mathrm{mg}$; thiamine $140 \mathrm{mg}$; riboflavin $230 \mathrm{mg}$; cobalamin $1,000 \mathrm{mg}$; biotin $7 \mathrm{mg}$; niaciamide $1,200 \mathrm{mg}$; folic acid $57 \mathrm{mg}$, calcium pantothenate $450 \mathrm{mg}$; choline chloride $6,000 \mathrm{mg}$; salinomycin sodium $2,333 \mathrm{mg}$.

Table 2. Analysis of the experimental diets - as fed basis (per kg of diet).

\begin{tabular}{lrrr}
\hline & HS0 & HS5 & HS15 \\
\hline Dry matter $(\mathrm{g})$ & 880.00 & 880.00 & 880.00 \\
AME $(\mathrm{MJ})^{*}$ & 12.81 & 12.86 & 12.68 \\
Crude protein $(\mathrm{g})$ & 188.56 & 191.62 & 199.56 \\
Ether extract $(\mathrm{g})$ & 71.60 & 83.53 & 84.11 \\
Crude fibre $(\mathrm{g})$ & 27.11 & 39.18 & 59.75 \\
Ash $(\mathrm{g})$ & 51.31 & 54.99 & 54.77 \\
\hline
\end{tabular}

Diet HS0 was the control, whereas HS5 and HS15 diets contained $50 \mathrm{~g} \cdot \mathrm{kg}^{-1}$ and $150 \mathrm{~g} \cdot \mathrm{kg}^{-1}$ of hempseed expellers, respectively.

* Apparent metabolizable energy - calculated value. the right deboned thigh was ground (Moulinex Moulinette, Caen, France). The dry matter and total fat contents of the meat were determined according to the Commission Regulation 152/2009. The crude protein content was analysed by an OPSIS Liquid Line (KjelROC Analyser, KD 310-A-1015, Furulund, Sweden) and calculated using the factor $6.25(\mathrm{~N} * 6.25)$ appropriate for meat. The content of total fat was determined gravimetrically after extraction with diethylether under reflux for $6 \mathrm{~h}$.

Texture and colour evaluation

The tenderness of the breast meat fillets ( 6 per group) and the Shear Force Values (Newton) were determined through the application of the Meullenet-Owens razor shear (MORS) test, using a texture analyser (Model TA-XT2Plus, Texture Technologies, Scarsdale, New York, U.S.A.) (Meullenet et al. 2004; Cavitt et al. 2005). The analysis using the MORS blade was conducted on whole intact right fillets (at least 5 replicates) using the following test settings: test speed $10 \mathrm{~mm} \cdot \mathrm{s}^{-}$ ${ }^{1}$, distance $20 \mathrm{~mm}$. Each measurement was performed on at least five meat samples.

The colour measurements (12 samples per group) were performed using the L*a*b* colour system (CIE 2007). The $\mathrm{L}^{*}$ (lightness), a* (redness, +/- red to green) and $b^{*}$ (yellowness, +/- yellow to blue) indicators from the breast muscle sample surface on the dorsal side were measured using the spectrophotometer CM-3500d (Konica Minolta Sensing Inc., Osaka, Japan) in specular component excluded (SCE) mode, angle $8^{\circ}, 8 \mathrm{~mm}$ slit. Each sample was measured at three separate locations on the surface 30 to 60 min post mortem. Each measurement was performed twice, and the mean was used. The mean values were calculated and used to calculate the differences in total colour $\Delta \mathrm{E}^{*}$ using the following formulas (CIE 2007; Valous et al. 2009):

\section{Sensory analysis}

Sensory properties of the breast $(n=6)$ and thigh $(n=6)$ muscles were evaluated by 10 panellists in the Sensory Laboratory (Department of Food Technology, Mendel University) using previously published methods (ISO 8589 1993). Each sample (breast and thigh) was packed in a plastic case and stored at $-18^{\circ} \mathrm{C}$. After two weeks, the samples were thawed at $4^{\circ} \mathrm{C}$ and cooked in a convection oven at $200{ }^{\circ} \mathrm{C}$ with $60 \%$ humidity for $1 \mathrm{~h}$. Professional evaluation groups that consisted of trained panellists were used for the sensory analysis (ISO 8586-1 2015). A graphic non-structured scale $(100 \mathrm{~mm}, 0=$ the worst, $100=$ the best $)$ was used to compare the experimental groups for odour, colour, fibreness, chewiness, juiciness, flavour, and fatty taste with the control group.

\section{Statistical analysis}

The data were analysed using one-way ANOVA with the StatSoft Statistica version 12.0 (Tulsa, Oklahoma, USA). To ensure evidential differences, Scheffe's test was applied and $P<0.05$ was considered as a significant difference. Statistical analyses were not used for $\Delta \mathrm{E}^{*}{ }_{\mathrm{ab}}$ because these values were obtained from the data reduction of CIE L*, a* and $\mathrm{b}^{*}$ coordinates. 
Table 3. Live weight (g) of broilers of the three experimental groups at day 37 .

\begin{tabular}{lc}
\hline Group & Mean \pm standard error \\
\hline HS0 & $2,300 \pm 36.84^{\mathrm{b}}$ \\
HS5 & $2,194 \pm 35.32^{\mathrm{ab}}$ \\
HS15 & $2,079 \pm 37.69^{\mathrm{a}}$ \\
\hline
\end{tabular}

a,b - Different superscripts represent significant differences $(P<0.05)$

Diet HS0 was the control, whereas HS5 and HS15 diets contained $50 \mathrm{~g} \cdot \mathrm{kg}^{-1}$ and $150 \mathrm{~g} \cdot \mathrm{kg}^{-1}$ of hempseed expellers, respectively.

\section{Results}

Growth performance and body composition

At the end of the trial the chickens in the control group had a significantly $(P<0.05)$ higher mean live weight $(2,300 \mathrm{~g})$ compared to the experimental groups. The lowest mean bodyweight $(2,079 \mathrm{~g})$ was from the chickens in the HS15 group (Table 3). The feed conversion ratio (FCR) in our study was $1.68,1.72$ and 1.83 for groups HS0, HS5 and HS15, respectively.

Table 4. Body composition (\%) of chickens.

\begin{tabular}{|c|c|c|c|}
\hline Group & HS0 & HS5 & HS15 \\
\hline $\mathrm{n}$ & 15 & 15 & 15 \\
\hline \multicolumn{4}{|c|}{ Mean \pm standard error } \\
\hline Carcass yield & $71.08 \pm 0.98$ & $72.56 \pm 0.73$ & $70.70 \pm 0.73$ \\
\hline Breast meat ${ }^{*}$ & $21.12 \pm 0.55$ & $21.74 \pm 0.50$ & $20.69 \pm 0.57$ \\
\hline Thigh meat* & $15.01 \pm 0.32$ & $15.28 \pm 0.34$ & $14.90 \pm 0.31$ \\
\hline
\end{tabular}

Differences between groups are not significant $(P>0.05)$; n means number of cases.

Diet HS0 was the control, whereas HS5 and HS15 diets contained $50 \mathrm{~g} \cdot \mathrm{kg}^{-1}$ and $150 \mathrm{~g} \cdot \mathrm{kg}^{-1} \mathrm{of} \mathrm{hempseed} \mathrm{expellers,}$ respectively.

* The breast and thigh meat were weighed, and their percentage of live body weight were calculated.

During the trial two deaths were recorded in the HS0 group of chickens, five deaths were recorded in the HS5 group and one death was recorded in the HS15 group.

Table 4 presents the body composition of chickens. There were no significant $(P>0.05)$ differences in the carcass composition indicating that the addition of hempseed expellers did not affect these indicators in chickens.

The chemical composition of breast and thigh meat is shown in the Table 5. The nutrient composition is an important characteristic used in meat quality evaluation. Differences among groups were not significant $(P>0.05)$.

Table 5. Chemical analysis of breast and thigh meat of broilers $\left(\mathrm{g} \cdot \mathrm{kg}^{-1}\right)$.

\begin{tabular}{llrrrr}
\hline & & & HS0 & HS5 & HS15 \\
\hline \multirow{2}{*}{ Dry matter } & $\mathrm{n}$ & & Mean \pm standard error & \\
& Breast meat & 6 & $239.7 \pm 0.6$ & $237.4 \pm 0.8$ & $242.3 \pm 0.5$ \\
& Thigh meat & & $246.2 \pm 0.4$ & $245.8 \pm 0.2$ & $240.8 \pm 0.3$ \\
\multirow{3}{*}{ Crude protein } & Breast meat & 6 & $218.2 \pm 0.8$ & $219.1 \pm 0.8$ & $217.7 \pm 0.6$ \\
& Thigh meat & & $194.5 \pm 0.2$ & $190.4 \pm 0.2$ & $193.4 \pm 0.3$ \\
\multirow{2}{*}{ Total fat } & Breast meat & 6 & $12.4 \pm 0.2$ & $10.7 \pm 0.1$ & $12.8 \pm 0.1$ \\
& Thigh meat & & $41.7 \pm 0.3$ & $45.1 \pm 0.3$ & $39.6 \pm 0.4$ \\
\hline
\end{tabular}

Differences between groups are not significant $(P>0.05)$; n means number of cases.

Diet HS0 was the control, whereas HS5 and HS15 diets contained $50 \mathrm{~g} \cdot \mathrm{kg}^{-1}$ and $150 \mathrm{~g} \cdot \mathrm{kg}^{-1} \mathrm{of} \mathrm{hempseed} \mathrm{expellers,}$ respectively. 


\section{Meat texture, colour and $\mathrm{pH}$}

Shear force values $(\mathrm{n}=6)$ are shown in Table 6; no significant differences in breast meat tenderness $(P>0.05)$ were observed between treatments.

The lightness $\left(\mathrm{L}^{*}\right)$ of the breast muscle was not significantly different $(P>0.05)$ between the different diets (Table 6). The $\mathrm{a}^{*}$ (redness) indicator had the maximum value in group HS15 $(5.40 \pm 0.40)$ which was significantly higher $(P<0.05)$ compared to the other groups. The higher level of hempseed expellers in the diet resulted in a higher intensity of red colour of the breast meat. Colour indicator $\mathrm{b}^{*}$ (yellowness) also had the highest value $(P<0.05)$ in group HS15 $(15.13 \pm 0.74)$. The $\mathrm{pH}$ values $\left(\mathrm{pH}_{1}\right.$ and $\left.\mathrm{pH}_{\mathrm{ull}}\right)$ were not significantly different $(P>0.05)$ between the experimental groups (Table 6).

Table 6. The effect of hempseed expellers dietary supplementation on texture, $\mathrm{pH}$ and colour indicators of breast meat (means \pm standard error).

\begin{tabular}{lcccc}
\hline Indicator & $\mathrm{n}$ & HS0 & HS5 & HS15 \\
\hline Shear force (N) & 6 & $11.23 \pm 0.47^{\mathrm{a}}$ & $10.74 \pm 0.53^{\mathrm{a}}$ & $11.38 \pm 0.47^{\mathrm{a}}$ \\
$\mathrm{L}^{*}$ & 12 & $62.00 \pm 1.36^{\mathrm{a}}$ & $64.41 \pm 0.76^{\mathrm{a}}$ & $62.66 \pm 1.09^{\mathrm{a}}$ \\
$\mathrm{a}^{*}$ & 12 & $4.42 \pm 0.38^{\mathrm{a}}$ & $4.23 \pm 0.21^{\mathrm{a}}$ & $5.40 \pm 0.40^{\mathrm{b}}$ \\
$\mathrm{b}^{*}$ & 12 & $11.33 \pm 0.98^{\mathrm{a}}$ & $12.16 \pm 0.58^{\mathrm{a}}$ & $15.13 \pm 0.74^{\mathrm{b}}$ \\
$\Delta \mathrm{E}^{*}{ }_{\mathrm{ab}}$ & & 0.00 & 2.55 & 3.64 \\
\hline $\mathrm{pH}_{1}$ & 6 & $6.40 \pm 0.08^{\mathrm{a}}$ & $6.44 \pm 0.07^{\mathrm{a}}$ & $6.62 \pm 0.08^{\mathrm{a}}$ \\
$\mathrm{pH}_{\text {ult }}$ & 6 & $6.12 \pm 0.07^{\mathrm{a}}$ & $6.16 \pm 0.07^{\mathrm{a}}$ & $6.18 \pm 0.09^{\mathrm{a}}$ \\
\hline
\end{tabular}

${ }^{\mathrm{a}, \mathrm{ab}}$ Different superscripts in a row mean significant differences $(P<0.05)$; $\mathrm{n}$ means number of cases.

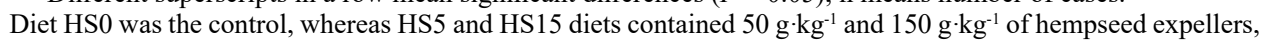
respectively.

$\mathrm{pH}_{1}$ and $\mathrm{pH}_{\text {ult }}$ values were measured 15 to $30 \mathrm{~min}$ and $6 \mathrm{~h}$ after slaughter in breast, respectively.

$\Delta \mathrm{E}^{*}{ }_{\mathrm{ab}}$ is compared with control group.

\section{Sensory analysis}

Odour reached the highest values in group HS15 $(P<0.05)$ for breast meat samples (Table 7) and colour reached lower values in the control compared to the experimental groups in thigh meat samples $(P<0.05$; Table 8$)$.

Table 7. Sensory analysis of chicken's breast meat.

\begin{tabular}{|c|c|c|c|c|}
\hline \multirow{2}{*}{ Group } & & HS0 & HS5 & HS15 \\
\hline & & \multicolumn{3}{|c|}{ Mean \pm standard error } \\
\hline Sensory trait & $\mathrm{n}$ & 60 & 60 & 60 \\
\hline Odour & & $63.97 \pm 2.75^{\mathrm{a}}$ & $65.07 \pm 2.19^{\mathrm{ab}}$ & $72.60 \pm 1.73^{b}$ \\
\hline Colour & & $73.18 \pm 1.45^{\mathrm{a}}$ & $73.75 \pm 1.22^{\mathrm{a}}$ & $76.95 \pm 1.41^{\mathrm{a}}$ \\
\hline Fibreness & & $55.18 \pm 2.62^{\mathrm{a}}$ & $51.28 \pm 2.40^{\mathrm{a}}$ & $59.50 \pm 2.44^{a}$ \\
\hline Chewiness & & $62.75 \pm 2.51^{\mathrm{a}}$ & $61.22 \pm 2.09^{\mathrm{a}}$ & $61.13 \pm 2.53^{\mathrm{a}}$ \\
\hline Juiciness & & $51.22 \pm 2.77^{\mathrm{a}}$ & $51.68 \pm 2.53^{\mathrm{a}}$ & $49.73 \pm 2.23^{\mathrm{a}}$ \\
\hline Flavour & & $74.00 \pm 1.50^{\mathrm{a}}$ & $71.73 \pm 1.27^{\mathrm{a}}$ & $73.27 \pm 2.16^{\mathrm{a}}$ \\
\hline Fatty taste & & $78.77 \pm 2.09^{\mathrm{a}}$ & $79.62 \pm 1.96^{\mathrm{a}}$ & $83.15 \pm 1.02$ \\
\hline
\end{tabular}

a, ab - Different superscripts in a row mean significant differences $(P<0.05)$; n means number of cases.

Diet HS0 was the control, whereas HS5 and HS15 diets contained $50 \mathrm{~g} \cdot \mathrm{kg}^{-1}$ and $150 \mathrm{~g} \cdot \mathrm{kg}^{-1} \mathrm{of} \mathrm{hempseed} \mathrm{expellers,}$ respectively. 
Table 8 . Sensory analysis of broilers thigh meat.

\begin{tabular}{|c|c|c|c|c|}
\hline \multirow{2}{*}{ Group } & & HSO & HS5 & HS 15 \\
\hline & & \multicolumn{3}{|c|}{ Mean \pm standard error } \\
\hline Sensory trait & $\mathrm{n}$ & 60 & 60 & 60 \\
\hline Odour & & $70.98 \pm 1.94^{\mathrm{a}}$ & $68.10 \pm 1.95^{\mathrm{a}}$ & $73.73 \pm 1.52^{a}$ \\
\hline Colour & & $50.08 \pm 1.19^{b}$ & $59.08 \pm 1.41^{\mathrm{a}}$ & $60.52 \pm 1.81^{\mathrm{a}}$ \\
\hline Fibreness & & $56.67 \pm 1.39^{\mathrm{a}}$ & $58.67 \pm 1.08^{\mathrm{a}}$ & $61.13 \pm 1.38^{\mathrm{a}}$ \\
\hline Chewiness & & $64.83 \pm 1.59^{\mathrm{a}}$ & $68.08 \pm 1.60^{\mathrm{a}}$ & $66.27 \pm 1.61^{\mathrm{a}}$ \\
\hline Juiciness & & $66.90 \pm 1.96^{\mathrm{a}}$ & $67.88 \pm 2.02^{\mathrm{a}}$ & $65.53 \pm 1.69^{\mathrm{a}}$ \\
\hline Flavour & & $74.25 \pm 1.87^{\mathrm{a}}$ & $70.53 \pm 2.00^{\mathrm{a}}$ & $67.12 \pm 2.61^{\mathrm{a}}$ \\
\hline Fatty taste & & $76.35 \pm 2.56^{\mathrm{a}}$ & $76.93 \pm 2.79^{a}$ & $75.42 \pm 2.52^{\mathrm{a}}$ \\
\hline
\end{tabular}

a a,b-Different superscripts in a row - significant differences $(P<0.05)$; n means number of cases.

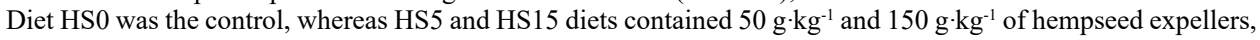
respectively.

\section{Discussion}

Overall in our study, the fattening of chickens decreased when a higher percentage of hempseed expellers was used in the feed. However, previous studies showed that the addition of $200 \mathrm{~g} \cdot \mathrm{kg}^{-1}$ of hempseed cakes to the chicken feed resulted in a chicken's weight of 1,194 $\mathrm{g}$ at 35 days (Eriksson and Wall 2012). This means that the chickens had a higher overall live weight at 37 days in this study. Given the FCR information in our study it is likely that differences in the live weight of chickens were caused by differences in the feed intake. The lower weight gains in the experimental groups are likely due to the higher content of fibre in the diet of the chickens that contained hempseed expellers. The diet of chickens in groups HS15 had the highest concentration of nutrients (Table 3) but the fibre in this diet was almost $6 \%$ which is higher than is recommended for broilers (Mateos et al. 2015). The content of $50 \mathrm{~g} \cdot \mathrm{kg}^{-1}$ hempseed expellers in chicken's diet did not significantly influence the live weight.

In previous studies, broilers fed conventionally with a diet containing $5 \%$ hempseed had a carcass yield of $61.3 \%$ and a live weight of $1,717 \mathrm{~g}$ at 42 days of age (Khan et al. 2010). Suchý et al. (2002) reported $25.99 \%$ of dry matter and $2.48 \%$ of fat content in breast muscle at day 42 . In the same study (Suchý et al. 2002), $27.19 \%$ of dry matter and $18.03 \%$ of crude protein was found in the thigh meat. In comparison, the values obtained in the present study were lower (apart from the protein content of thigh meat) due to the shorter length of the fattening period which was 37 days compared to 42 days. However, in the same study (Suchý et al. 2002), 7.69\% of crude fat in thigh meat was found. This value is higher compared to that observed in our study, indicating that apart from the length of the fattening period, it is also necessary to consider the hybrid, diet and housing conditions for making proper comparisons.

The higher levels of hempseed expellers in the diet also caused a higher intensity of yellow to orange colour in the breast muscle. Poultry meat colour is easily influenced by dietary manipulation. Carotenoids in feeds can increase the pigmentation in bird muscle (Toyomizu et al. 2001). Yellowness could be associated with a higher content of carotenoids ( $\beta$-carotene, $\alpha$-carotene, lutein and zeaxanthin) in feeds (Rodriguez-Amaya 2016). A total colour change ( $\Delta \mathrm{E}^{*}$ ab from 1.5 to 3.0) can be observed, however, this was found to be still acceptable for consumers (Salakova 2012). The scale for $\Delta \mathrm{E}^{*}$ ab indicates the degree of the mismatching of two colours (Zmeskal et al. 2002). The calculated values of $\Delta \mathrm{E}^{*}$ ab in group HS5 falls into the category of slight perceived difference, which is not 
disturbing. The calculated value of $\Delta \mathrm{E}^{*}$ ab for group HS15 falls into the category of medium difference. The control group with a zero value falls into the category of imperceptible difference.

The measured $\mathrm{pH}_{\text {ult }}$ values can be categorized as normal, since they did not exceed value 6.2 (dark, firm, dry -DFD; Owens et al. 2009; Adzitey and Nurul 2011). Previous studies that examined the same indicators as the present study (chemical composition, $\mathrm{pH}$, shear force and colour indicators of breast meat) but in different rearing systems found values that are consistent with those of the present study (Michalczuk et al. 2014). Their evaluation of chickens' breast meat was consistent with our results and they observed that the rearing system did not affect the proximate chemical composition and physicochemical properties of breast muscles (Michalczuk et al. 2014). The sensory evaluation of meat is directly influenced by tenderness which is determined by measuring shear force (Michalczuk et al. 2014).

During sensory evaluation, higher scores for juiciness were observed for thigh than breast meat samples (Table 7 and 8). Kokoszynski et al. (2016) have reached the same conclusions.

As shown, the observed differences in $\mathrm{a}^{*}$ and $\mathrm{b}^{*}$ colour indicators in group HS15 were not "illustrated" in the sensory evaluation analysis. Dietary supplementation with hempseed expellers appeared not to affect the organoleptic characteristics of broiler meat. Consumers easily accept darker meat with lower $\mathrm{L}^{*}$ and simultaneously with higher $\mathrm{a}^{*}$ and $\mathrm{b}$ * than e.g. meat that is significantly paler or discoloured with white stripes (Kuttappan et al. 2012).

Based on the results it can be concluded that the examined indicators of quality and sensory attributes of meat were not generally affected by the addition of the hempseed expellers. Other monitored indicators of performance, quality and sensory properties of the meat were not affected by the addition of hempseed expellers with exception of thigh muscle colour and breast muscle odour. Breast meat was evaluated as the best in terms of odour. The colour of thigh meat was better rated in the hempseed expellers supplemented groups compared to the controls. It can be stated that a lower concentration of hempseed expellers $\left(50 \mathrm{~g} \cdot \mathrm{kg}^{-1}\right)$ can be used to feed chickens without adverse effects on their performance or composition and sensory characteristics of the meat. A higher proportion of expellers had a positive impact on some sensory properties of the meat. In conclusion, dietary supplementation with hempseed expellers appears to affect the colour and odour of broiler chicken's meat which is positive for the consumers. Inclusion of hempseed cakes can be recommended as a component of broiler chickens feed.

\section{Acknowledgements}

The research was financially supported by the TP IGA FA MENDELU 4/2015. All authors thank prof. Amanda J. Deering (Purdue University, USA) for proofreading the English.

\section{References}

Adzitey F, Nurul H 2011: Pale soft exudative (PSE) and dark firm dry (DFD) meats: causes and measures to reduce these incidences-a mini review. Int Food Res J 18: 11-20

Bulda OV, Rassadina VV, Alekseichuk HN, Laman NA 2008: Spectrophotometric measurement of carotenes, xanthophylls, and chlorophylls in extracts from plant seeds. Russ J Plant Physl 55: 544-551

Callaway JC 2004: Hempseed as a nutritional resource: An overview. Euphytica 140: 65-72

Cavitt LC, Meullenet JF, Xiong R, Owens CM 2005: The relationship of razor blade shear, Allo-Kramer shear, Warner-Bratzler shear and sensory tests to changes in tenderness of broiler breast fillets. J Muscle Foods 16: 223-242

CIE. Colorimetry, part 4. 2007. CIE 1976 L*a*b* Colour space. CIE Central Bureau, Vienna, CIE DS 014-4.3/E:2007

Commission regulation (EC) 152/2009. Laying down the methods of sampling and analysis for the official control of feed. Brussels: The commission of the European Communities.

Eriksson M, Wall H 2012: Hemp seed cake in organic broiler diets. Anim Feed Sci Tech 171: 205-213 
Glamoclija N, Starcevic M, Janjic J, Ivanovic J, Boskovic M, Djordjevic J, Baltic MZ 2015: The effect of breed line and age on measurements of $\mathrm{pH}$-value as meat quality parameter in breast muscles ( $\mathrm{m}$. pectoralis major) of broiler chickens. Proc Food Sci 5: 89-92

Grabowski T 2014: Technology of poultry peat (in Polish) In Michalczuk M, Lukasiewicz M, ZdanowskaSasiadek Z, Niemiec J 2014: Comparison of selected quality attributes of chicken meat as affected by rearing systems. Pol J Food Nutr Sci 64: 121-126

Hampson AJ, Grimaldi M, Axelrod J, Wink D 1998: Cannabidiol and 9-tetrahydrocannabinol are neuroprotective antioxidants. P Natl A Sci 95: 8268-8273

Hampson AJ, Grimaldi M, Lolic M, Wink D, Rosenthal R, Axelrod J 2000: Neuroprotective antioxidants from marijuana. Ann NY Acad Sci 899: 274-282

ISO 8586-1. 2015. Sensory analysis - General guidelines for the selection, training and monitoring of selected assessors and expert sensory assessors. Geneva: International Organization for Standardization

ISO 8589. 1993. Sensory analysis - General guidance for the design of test rooms. Geneva: International Organization for Standardization

Karlsson L, Finell M, Martinsson K 2010: Effects of increasing amounts of hempseed cake in the diet of dairy cows on the production and composition of milk. Animal 4: 1854-1860

Khan RU, Durrani FR, Chand N, Anwar H 2010: Influence of feed supplementation with Cannabis sativa on quality of broilers carcass. Pak Vet J 30: $34-38$

Koch JE 2001: Delta 9-THC stimulates food intake in Lewis rats: effects on chow, high-fat and sweet high-fat diets. Pharmacol Biochem Be 68: 539-543

Kokoszynski D, Bernacki Z, Steczny K, Saleh M, Wasilewski PD, Kotowicz M, Wasilewski R, Biegniewska M, Grzonkowska K 2016: Comparison of carcass composition, physicochemical and sensory traits of meat from spent broiler breeders with broilers. Eur Poultry Sci 80: 1-11

Kuttappan VA, Lee YS, Erf GF, Meullenet JFC, McKee SR, Owens CM 2012: Consumer acceptance of visual appearance of broiler breast meat with varying degrees of white striping. Poultry Sci 91: 1240-1247

Lalge AB, Mendel P, Vyhnanek T, Trojan V, Fiserova H, Hřivna L, Mrkvicova E, Havel L 2016: GC-FID analysis of food samples made of hemp. In MendelNet 2016: Proceedings of International PhD Students Conference: 600-604

Mateos GG, Jimenez-Moreno E, Serrano MP, Lazaro RP 2015: Poultry response to high levels of dietary fiber sources varying in physical and chemical characteristics. J App Poult Res 21: 156-174

Meullenet JF, Jonville E, Grezes D, Owens CM 2004: Prediction of the texture of cooked poultry pectoralis major muscles by near-infrared reflectance analysis of raw meat. J Texture Stud 35: 573-585

Michalczuk M, Lukasiewicz M, Zdanowska-Sasiadek Z, Niemiec J 2014: Comparison of selected quality attributes of chicken meat as affected by rearing systems. Pol J Food Nutr Sci 64: 121-126

Obradovic V, Babic J, Subaric D, Ackar D, Jozinovic A 2014: Improvement of nutritional and functional properties of extruded food products. J Food Nutr Res 53: 189-206

Owens CM, Alvarado CZ, Sams AR 2009: Research developments in pale, soft, and exudative turkey meat in North America. Poultry Sci 88: 1513-1517

Rodriguez-Amaya DB 2016: Natural food pigments and colorants. Curr Opin Food Sci 7: 20-26

Salakova A 2012: Instrumental measurement of texture and color of meat and meat products. Maso International Brno 2: 107-114

Straus SE 2001: Immunoactive cannabinoids: therapeutic prospects for marijuana constituents. P Natl Acad Sci USA 97: 9363-9364

Suchý P, Jelinek P, Strakova E, Hucl J 2002: Chemical composition of muscles of hybrid broiler chickens during prolonged feeding. Czech J Anim Sci 47: 511-518

Technological procedure for broiler Ross [online]. Aviagen Group. 2014. [2017-3-21]. Available at: http://en.aviagen.com/ross-308. (accessed May 28, 2018).

Toyomizu M, Sato K, Taroda H, Kato T, Akiba Y 2001: Effects of dietary spirulina on meat colour in muscle of broiler chickens. Brit Poultry Sci 42: 197-202

Valous NA, Mendoza F, Sun DW, Allen P 2009: Colour calibration of a laboratory computer vision system for quality evaluation of pre-sliced hams. Meat Sci 81: 132-141

Varga M, Bánhidy J, Cseuz L, Matuz J. 2013: The anthocyanin content of blue and purple coloured wheat cultivars and their hybrid generations. Cereal Res Commun 41: 284-292

Zelenka J, Heger J, Zeman L 2007: Recommended nutrient content in poultry diets and nutritive value of feeds for poultry (in Czech). Mendel University in Brno.

Zmeskal O, Ceppan M, Dzik P 2002: Color spaces and color management 10: 1-14. Avaliable at: http://www.fch. vut.cz/lectures/imagesci/download/stud06_rozn02.pdf (Accessed May 28, 2018). 